KAIROS ELT JOURNAL, Vol. 2, No. 1, April 2018

Copyright@2018, ISSN: 2580-4278

\title{
IMPROVING STUDENTS' VOCABULARY MASTERY THROUGH WORD WALLS STRATEGY TO THE EIGHTH GRADE STUDENTS OF SMP SWASTA KARYA BHAKTI MEDAN
}

\author{
Hotmariana Sinaga, Rosa Simamora, Anna Stasya Prima Sari \\ Catholic University of Saint Thomas
}

\begin{abstract}
This study is aimed to improve students' vocabulary mastery through word walls strategy. This strategy is one of appropriate strategies in improving students' vocabulary mastery. The subject of this study is the eighth grade students of SMP Swasta Karya Bhakti Medan Class VIII A in the Academic Year of 2016/2017. This study was conducted by applying Classroom Action Research (CAR), which was performed in two cycles (cycle I and Cycle II) and each cycle consisted of three meetings. The instruments of collecting data were quantitative data (vocabulary tests) and qualitative data (observation sheets, daily notes, and photograph evidences). The results of vocabulary tests showed that the mean of the students' score increased continuously from pre-test $(8 \%)$, formative test in cycle I $(44 \%)$ to post-test in cycle II $(92 \%)$. The observation sheets, daily notes, and photograph evidences showed that the students are interested in the teaching and learning processes through word walls strategy and this study ran well. It was found that word walls strategy could improve students' vocabulary mastery. It is suggested that teachers of English should apply word walls strategy as one of the strategies in teaching vocabulary mastery.
\end{abstract}

Keywords: vocabulary mastery, word walls

\section{INTRODUCTION}

English is an international language which is widely used by many people in the world. Langan (1990) states, "A good vocabulary is a vital part of effective communication. A command of many words will make you a better writer, speaker, listener and reader" (p.341). That is why English becomes the second language and foreign language for many people around the world.

There are four language skills in learning English. They are listening, speaking, reading, and writing. Students are expected to be able to communicate well in English language through listening, speaking, reading and writing. To reach this goal, students should learn and master a large number of vocabularies. Through vocabulary, we can convey our ideas, emotions and experiences efficiently. Without mastering it, people will not be able to use English effectively. Wilkins in Thornbury (2002) states "Without grammar very little can be conveyed, without vocabulary nothing can be conveyed" (p.13). Students must continue to learn words as they learn structure as they practice in the target language. The vocabulary is needed to master the four skills in the English language.

Mastering vocabulary is the ability to get or to receive lots of words. Having and mastering vocabulary makes us easier to understand English texts well. It can also help us avoid making mistakes in understanding written or spoken texts. In order to understand the language, vocabulary is crucial to be mastered by the learners. Rivers (2010) states, "Vocabulary mastery refers to the great skill in processing words of language. It is an individual achievement and possession" (p.16). Vocabulary mastery plays important role in the four language skills and it has to be considered that vocabulary mastery is one of the needed components of language.

Teaching vocabulary is important for learners especially for young learners because the mastery of a certain of words would motivate them to express themselves clearly. Grabe (2009) 
states that a new issue of current review about vocabulary mastery, stressing on the importance of (a) making students aware of using the new words they encounter and (b) motivating the students to learn and use the new words, more over they need to be collectors of words either by listing words which are interesting or difficult, or by nothing possible connection between new words and known words or trying to use the new words in some interesting way(Limbong \& Simarmata, 2020).

Based on the observation done by the writer to the eighth grade students of SMP Swasta Karya Bhakti Medan Class VIII A in the Academic Year of 2016/2017, it was found that the students faced many problems in learning vocabulary. The students showed that the difficulty of learning English coming from their vocabulary mastery. In addition, the writer found several problems about students' vocabulary mastery such as difficulty in understanding the meaning of words, in pronouncing English words correctly and the students could not spell the words correctly. The factors that cause these problems are the way how English words are written is different from the way of how they are pronounced and the students have lack of motivation in learning English.

The writer interviewed Mrs.SS, the English teacher at the school about the students' vocabulary mastery. She said that the students' vocabulary mastery is poor. It is difficult for the students to master vocabularies when they find difficult words in English texts because they lack of English vocabularies. The writer interviewed two students about that case. They are AP and LM, they said that English is a difficult subject and many words of English were unfamiliar to them so the students face difficulties in mastering the vocabularies.

These phenomena motivated the writer to find a strategy in order to solve the problems. The appropriate strategy for teaching English vocabularies is very important because it will determine the result. There are many strategies that are appropriate in teaching English vocabularies especially to improve the students' vocabulary mastery such as cognitive strategy, missing words, vocabulary notebook or journal, semantic features analysis, experimental learning, word walls strategy. In order to improve the students' vocabulary mastery, the writer applied word walls strategy.

The writer chose this strategy because some research findings have shown good result of teaching English vocabularies through word walls strategy. The first research was carried out by Anggriani (2012) entitled 'Improving Students' Vocabulary Achievement through Word Walls Strategy", she concluded that the use of word walls strategy was enjoyable in teaching English, especially in improving students' vocabulary mastery. By using word walls strategy, students were interested in learning English vocabulary mastery. The second is a journal by Huzairin, Hasan \& Istianto (2013) entitled "Improving Students' Vocabulary Mastery through Word Wall". It is stated that word wall can be used to increase students' vocabulary mastery. It statically had been proven by the increase of the students' mean score in posttest that is higher than the mean score in pretest. The mean score increased from 54 in pretest to 81.07 in posttest. The third research was carried out by Sari (2105) entitled "The Making of Word Wall to Improve Elemetary School Students English Vocabulary" which shown a good result.

This study is important to conduct because if it is not conducted, teachers will not be able to know students' problems in mastering vocabulary and how to improve their vocabulary. If language teachers do not know the students' problem in mastering vocabulary, so students will not get feedback from their teachers in order to be able to comprehend English texts. Meanwhile if this study is conducted, it will give some positive impacts. This study will be useful for language teachers. So they will be able to know how far students have improvement in mastering vocabulary. As a result, teachers will be able to develop curriculum design and chose an appropriate treatment to help students in improving students' vocabulary mastery. 
Based to the explanation above, the writer decided to conduct a research entitled Improving Students' Vocabulary Mastery through Word Walls Strategy to the eighth grade students of SMP Swasta Karya Bakti Medan Class A in the Academic Year of 2016/2017.

\section{REVIEW OF LITERATURE Vocabulary Mastery}

Vocabulary is not only sign or symbol for ideas but also a part of how to improve language skills in the target language. Vocabulary is a very important means to express our thoughts and feeling, either in spoken or written forms. The more vocabulary students learn, the more ideas they should have, so they can communicate by using their ideas more effectively.

Grabe (2009) states that raising the students' awareness of the new words that they encounter in texts represents an important learning goal. The students must be aware of the vocabularies. It means that the students must be able to recognize its meaning, and the pronunciation.

Mastering English vocabulary in the process of teaching and learning English in Junior High School is very important. By having or mastering a stock of words, someone will be able to communicate with other people easily and fluently. Vocabulary as one of important component in learning English language cannot be ignored. Without mastering English vocabulary, the students cannot master English language easily.

\section{The Importance of Vocabulary}

Vocabulary is important because it is the owning system of communication. Communication is supported by large vocabularies mastery as a basic competence. It is difficult for the students to comprehend the spoken and written English without mastering large vocabularies. Wallace (1982) mentions two main reasons about the importance of vocabulary. They are: 1) language exists in two forms, spoken and written, both of them need vocabulary to develop the existence itself, and 2) vocabulary is needed for production in learning English as a foreign language rather than only needed for recognition it. So students will be able to speak concisely and precisely, better understand what they read and hear by mastering large vocabularies.

By having a lot of vocabularies, we can improve our English. Vocabulary buildings are very important in any language learning not only because it has a close correlation with the intellectual maturity of the learners but also it helps a great deal to improve of the four language skills. The students will be given an opportunity to analyze the new words that will be enlarged in sentences. The writer will design the teaching material as well as possible, in order to facilitate the students in improving their vocabularies.

\section{Types of Vocabulary}

Talking about vocabulary it is necessary to present the types of vocabulary when one speaks to others. He needs some words to express his idea desire or when he listens, he must be able to catch the meaning. Stahl (1999) states that there are four types of vocabulary which must be known and mastered for any skills, such as listening, speaking, reading and writing. They are (a) Listening vocabulary is all the words he or she can recognize when listening to speech. They are the stock of words to which one responding with meaning and understanding in speech of others. (b) Reading vocabulary is all the words he or she can recognize when reading. (c) Speaking vocabulary is all the words that personable use in speech. Due to spontaneous nature of speaking vocabulary, words are often misused. When one speaks, may be compensated by facial expressions, tone of voice or hand gestures.(d) Writing vocabulary 
is all the words people can employ in writing. It is relating to the second type of vocabulary that is simulated by its user.

In this study, the writer will focus on improving students' reading vocabulary. If students' vocabulary mastery has been built up, they will be able to comprehend English texts. Here, the writer expected that students would be able to build up their vocabulary mastery when they are reading English texts. Teaching and learning is a process to grasp information from the teacher but also involve variety of activities and the act must be performed in order to obtain the good achievement.

\section{Strategies}

Strategy is a method or plan chosen to bring about a desired future, such as achievement of a goal or solution to a problem. Brown (2000) states that strategy as specific methods of approaching a problem or task, mode of operation for achieving a particular end, planned design for controlling and manipulating certain information. He further states that there are three main categories of strategy. They are: (a) meta cognitive strategies involve planning learning, thinking about the learning process as it is taking place, monitoring of one's production or comprehension, and evaluating learning after an activity is completed, (b) cognitive strategies are more limited of specific learning task and involve more direct manipulation of learning material itself and (c) socio strategies have to be done with social mediating activity and interacting with others.

There are a number of strategies in http://vprojas@aol.com. The strategies were appropriate in teaching English specially to improve the students' vocabulary mastery. They are (1) Mind mapping - this strategy teaches students the meaning of key concepts by helping them understand the essential attributes, qualities, or characteristics of a word's meaning, (2) Missing words - an adaptation of the cloze procedure - engages students in reading a selection with certain words deleted, and then predicting in writing the missing words. It helps students learn to draw upon prior knowledge, use meta-cognitive skills, think inferentially, and understand relationships, (3) Vocabulary notebook or journal - After reading or discussing, students keep track of their vocabulary development in a notebook or journal by recording how a word is used in different contexts, sketching what it means, and providing meaningful examples which links to their lives. Notebook and journals can be shared with peers, (4) Word walls strategy are organized alphabetically, with words printed on card stock, and taped or pinned to the wall/board. Teachers are encouraged to be creative in designing word walls so that it engages the students and enhances their learning. Building a word wall can be easily integrated into daily activities. Key words and/or terminologies that relate to the lesson or unit of study can be added gradually as they are introduced. Word walls should be organized in a way that is useful to students with additions reflecting the skills or concepts being taught.

The writer chose word walls strategy because it is one of appropriate strategies in improving students' vocabulary mastery. Some research findings also have shown good result of teaching English vocabulary through word walls strategy like has been mentioned on the background of the study. The students were interested in learning vocabulary because the classroom wall was adorned with new words.

\section{The Word Walls Strategy}

Thompkins (1997) states that word walls strategy is alphabetical list of words created in the classroom for the purpose of word study and vocabulary development. They can be as simple as a list of words written on a large sheet of butcher paper. In classroom where students are learning English as a second language it is useful to create word walls with the words written in English and the meaning in Indonesian. 
Word walls serve as a reference for students as they write or interact verbally. According to Thompkins (1997) the types of word walls strategy and suggestion for displaying them are as follows:

a. High - frequency words

1) Alphabetical list on large sheets of butcher paper.

2) Large bulletin boards into which individual words are added in alphabetical order.

3) Clotheslines which strung across the room into which large cards with a single alphabet letter are attached. Word cards are then stapled to the alphabet letter to form the word list for each letter.

b. Literature Word walls

1) Interesting, difficult, and unusual words from the story being studied are placed in a pocked chart and arranged alphabetically.

2) The words may be arranged on a sheet of butcher paper in the shape of something related to the story like a covered wagon or hot-air balloon.

3) The words may be collected in a container that relates to the story such as a witch's cauldron or miniature windmill.

c. Content - area word walls

1) Interesting words are written on cards and displayed on a pocket chart.

2) Words are collecting by entering them in the computer and printing out a large poster that is updated periodical.

The writer will create high-frequency words which can be used by students as a reference to write sentences. They were asked to pronounce and spell the words from the word walls. The writer guided the students to write down their own sentences.

\section{The Advantages of Using Word Walls Strategy}

There are some advantages of using word walls strategy in the classroom as found in http://www.readingrockets.org/strategies/word_walls they are: (a) they provide a permanent model for high frequency words, (b) they help students see patterns and relationship in words, thus building phonics and spelling skills and (c) they provide reference support for children during reading and writing activities. All the advantages of word walls strategy above made the writer easier in improving students' vocabulary mastery. It also made the writer encouraged to use the strategy to conduct this study using word walls strategy.

\section{Steps in Implementing Word Walls Strategy}

According to Thompkins (1997) in teaching vocabulary, there are three steps in implementing word walls strategy, they are: (1) Beginning word study, in this step the writer decided the format that was used and began by brainstorming a list of words with the students. To arrange the words in alphabetical order for easy access, write the words on individual cards and tape them on a wall or place them in a pocket chart. Involve the students in selecting words to be added to the word walls. (2) The writer made words accessible by putting them where every student can see them. The words were written on large letters using a variety of background colors to distinguish easily confusing word. The writer was selective about the words that go on the word wall. Try to include words that students use most commonly. (3) Using the word walls, this step refers to the word walls whenever a word is discussed. Help the students to see the possibilities for the use of the word walls. If students ask for the spelling of a word that is posted, draw the students' attention to it. The writer provided enough practice so that words were read and spelled automatically and made sure that word walls are always spelled correctly. (4) Keep the word walls interactive, in this step the writer used the words for activities such as spelling and pronouncing the words. 


\section{RESEARCH METHOD}

The research design that was used in this study is Classroom Action Research (CAR). The writer followed the steps of Classroom Action Research (CAR) which were proposed by Kemmis \& Mc.Taggard in Burns (2010). Mettetal (2001) states that Classroom Action Research (CAR) is a method of finding out what works best in your own classroom so that you can improve student learning. Furthermore he states that the goal of Classroom Action Research (CAR) is to improve your own teaching in your own classroom. In Classroom Action Research (CAR) the writer focused on the problems in her own classroom.

Richard \& Farrell (2005) state that the action research has three characteristics, they are (a) Its primary goal is to improve teaching and learning in schools and classrooms and it is conducted during the process of regular classroom teaching. (b) It is usually small-scale and intended to help resolve problems rather than simply be research for its own sake. (c) It can be carried out by an individual teacher or collaboration with other teachers. The writer conducted the study based to the characteristics of classroom action research above.

The writer conducted the research in four phases: planning, action, observation, and reflection. This study was conducted in two cycles. The following is the cyclical Classroom Action Research (CAR) model based on Kemmis \& Mc.Taggart in Burns (2010).

CYCLE 1



Figure 1. Cyclical Classroom Action Research (CAR) Model Based on Kemmis \& Mc.Taggart in Burns (2010)

The following are the explanations of the four phases which are based on Kemmis \& Mc.Taggart in Burns (2010).

\section{Planning}

In this phase the writer identified problems and developed a plan of action in order to bring about improvements in a specific area of the research context. This was a forward-looking phase where the writer considered: i) what kind of investigation is possible between the realities 
and constraints of her teaching situation and ii) what potential instruments she thinks were possible.

\section{Action}

The plan was a carefully one which involved some deliberate interventions into the writer's teaching situation that she put into action over an agreed period of time. After forming the planning, the writer implemented the word walls strategy. Based on the discussion with the teacher before, the writer became the teacher while the teacher became the observer who observed the teaching and learning processes that was done by the writer. In implementing the word walls strategy the writer used teaching and learning activities; pre activities, whilst activities, and post activities.

\section{Observation}

In this phase, the writer observed the effects of the actions on the teaching and learning process systematically. It was a data collection phase where the writer collected information about what was happening during the teaching and the learning processes.

\section{Reflection}

At this point, the writer reflected on, evaluated and described the effects of the action in order to make sense of what has happened. Here the writer decided to do further cycles to improve the situation of her Classroom Action Research (CAR) .

\section{DATA ANALYSIS \\ Data Analysis}

The quantitative data was taken from the result that consisted of 25 items of vocabulary test. The vocabulary test was relevant with the topic which has been taught by the teacher in the classroom. The total score from the pre-test is 48.96, in formative test is 67.12 and in posttest in cycle II the total score is 80 .

The mean of the students' score in formative test and the post-test are higher than the pre-test. It means that students' vocabulary mastery has improved significantly it is from 48.96 to 80 . It proved that word walls strategy is one of appropriate strategies in improving the students' vocabulary mastery.

Based on the analysis, it can be concluded that all of the students have improvement on their vocabulary mastery. There was a high improvement and also low improvement. The range of the improvement of students' vocabulary mastery can be seen at the scoring of students' test.

\section{Scoring of the Test}

As we seen in the table, the students' score increases from the pre-test until the posttest. The writer gave the students 25 items of vocabulary test for pre-test, formative test and post-test. It was found out that the students' scores of the vocabulary test kept improving from the beginning to the last meetings. The students' score in the formative test is higher than the pre-test, and the post-test is higher than post-test formative test.

From the result of the student' mean scores, it can be concluded that the students' vocabulary mastery has been improved in the teaching and learning processes of vocabulary through the word walls strategy. The students were active during the teaching and learning processes. They always gave their attention to the teacher. To find out the percentage of the students' improvement on pre-test, formative test and post-tes, the writer determined the criterion to the PAP (Penilaian Acuan Patokan) as follows:

Table 1. Data Frequency Distribution for Students Score of Pre-test

\begin{tabular}{|l|l|l|l|l|l|}
\hline No & Score Interval & Frequency & Percentage & The Quality & Category \\
\hline 1 & $85-100$ & 0 & $0 \%$ & A & VERY HIGH \\
\hline
\end{tabular}


KAIROS ELT JOURNAL, Vol. 2, No. 1, April 2018

Copyright@ 02018 , ISSN: 2580-4278

\begin{tabular}{|l|l|l|l|l|l|}
2 & $70-84$ & 2 & $8 \%$ & B & HIGH \\
\hline 3 & $60-69$ & 3 & $12 \%$ & C & AVERAGE \\
\hline 4 & $50-59$ & 5 & $20 \%$ & D & LOW \\
\hline 5 & $0-49$ & 15 & $60 \%$ & E & VERY LOW \\
\hline
\end{tabular}

Table 2. Data Frequency Distribution for Score of Formative Test

\begin{tabular}{|l|l|l|l|l|l|}
\hline No & Score Interval & Frequency & Percentage & The Quality & Category \\
\hline 1 & $85-100$ & 0 & $0 \%$ & A & VERY HIGH \\
\hline 2 & $70-84$ & 11 & $44 \%$ & B & HIGH \\
\hline 3 & $60-69$ & 11 & $44 \%$ & C & AVERAGE \\
\hline 4 & $50-59$ & 3 & $12 \%$ & D & LOW \\
\hline 5 & $0-49$ & 0 & $0 \%$ & E & VERY LOW \\
\hline
\end{tabular}

Table 3. Data Frequency Distribution for Score of Post-test II

\begin{tabular}{|l|l|l|l|l|l|}
\hline No & Score Interval & Frequency & Percentage & The Quality & Category \\
\hline 1 & $85-100$ & 7 & $28 \%$ & A & VERY HIGH \\
\hline 2 & $70-84$ & 16 & $64 \%$ & B & HIGH \\
\hline 3 & $60-69$ & 2 & $8 \%$ & C & AVERAGE \\
\hline 4 & $50-59$ & 0 & $0 \%$ & D & LOW \\
\hline 5 & $0-49$ & 0 & $0 \%$ & E & VERY LOW \\
\hline
\end{tabular}

From the students' scores which show the improvement on their vocabulary test it proves that they showed a progress. The students' improvement on their vocabulary test through the word walls strategy is seen from the students' mean score.

$\mathbf{M}=\frac{\sum \mathbf{x}}{\mathbf{N}}$

Where: $\quad M=$ the mean of students' score

$\sum \mathrm{x}=$ the total score

$\mathrm{N}=$ the total number of students who do the test

The students' mean score in cycle I is:

In the first meeting the students did the pre-test, the total score of the students' test is 1224 and the total number of students who did the test are 25 students, so the mean of the students' score is:

$\mathrm{M}=\frac{1224}{25}=48.96$

In the third meeting the students did the formative test. The total score of the students' mean score is 1678 and the total number of students who did the test are 25 students, so the mean of the students' score is:

$\mathrm{M}=\frac{1678}{25}=67.12$

The students' mean score in cycle II is:

In the eight meeting the students did the post-test, the total score is 2000 and the total number of students who done the test is 25 , so the mean score of the students' score is:

$\mathrm{M}=\frac{2000}{25}=80$

The students' mean score in post-test is the highest of all the tests. In the first cycle, the pre-test is 48.96 and the post-test $I$ is 67.12 . In the second cycle the post-test is 80 . The mean of the students' score shown that the students' vocabulary mastery has been improved, it can

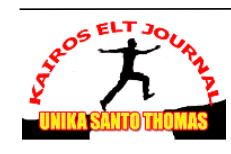


be seen from the students' mean score from the first test up to the third test. It can be concluded that the use of the word walls strategy can improve students' vocabulary mastery.

In this study, the indicator of students who succeed on mastering vocabulary is if $70 \%$ of students who have got mean score $\geq 70$ on their vocabulary test. The number of students who are competent on vocabulary is calculated by applying the following formula:

$$
\mathbf{P}=\frac{\mathbf{R}}{\mathbf{T}} \mathbf{x} \mathbf{1 0 0} \%
$$

Where: $\mathrm{P}=$ the percentage of students who get the point $\geq 70$

$\mathrm{R}=$ the number of students who get point $\geq 70$

$\mathrm{T}=$ the total number of students who do the test

The percentage of the improvement of students' vocabulary can be seen by applying the following formula:

$\begin{array}{ll}\text { Pre-test } & : \mathrm{P}=\frac{2}{25} \times 100 \%=8 \% \\ \text { Formative Test } & : \mathrm{P}=\frac{11}{25} \times 100 \%=44 \% \\ \text { Post-test II } & : \mathrm{P}=\frac{23}{25} \times 100 \%=92 \%\end{array}$

The students master the lesson if they get score $\geq 70$. The percentage of students who get the point $\geq 70$ shows the improvement of students' score on vocabulary test from the first test to the third test. It can be seen from the table below:

Table 4.The Percentage of Students who got the Point $\geq 70$

\begin{tabular}{|l|l|}
\hline Competence Test & Percentage \\
\hline Pre-test & $8 \%$ \\
\hline Formative Test & $44 \%$ \\
\hline Post-Test & $92 \%$ \\
\hline
\end{tabular}

The result of students' percentage who get the point $\geq 70$ on their vocabulary test shows that the students' capability improves in the formative test and they have significant improvement in post-test. In the pre-test there is only $8 \%$ (two students) who got point $\geq 70$.

In the formative test there was an increase of the students' percentage who got score $\geq 70$ namely $44 \%$ (11 students). In the formative test, the students did not get significant improvement from the pre-test to the formative test, although the teacher had applied the word walls strategy in the process of teaching vocabulary. Many students were not serious and active in doing the task because they need more motivation and time. In the observation sheet and the diary notes showed that many students were not interested in the teacher's explanation about the word walls strategy, they did not want and were not confident to ask about the topic given by the teacher and sometimes their noise disturbed the teaching and learning process because the lack of understanding about the importance of learning English. So based to the reason the writer continued to the next cycle and give more motivation to the students in order to get significant improvement on their vocabulary mastery.

In the post-test there are $92 \%$ (23 students) who got point $\geq 70$ but in the cycle II, there are 2 students who got point $\leq 70$. Eventhough they did not get point $\geq 70$, but their score kept improving from the pre-test until the post-test. In cycle II, the teacher still applied the word walls strategy and explained it more detail. Some additional activities based on the reflection which done by the teacher and the collaborator to avoid the same mistake in the cycle I and to get better improvement of their score on their vocabulary test. Teacher motivated the students to generate their interest in learning English, gave punishment to the noisy students to sit in front, gave more changes to the students, especially in learning English through the word walls 
strategy and attention to the students who were not confident to present their works or ask what they did not understand.

\section{Research Findings}

The finding of this research is that the word walls strategy can help the students to improve their vocabulary mastery. By applying this strategy, the score of the students in vocabulary test kept increasing from the pre-test until the post-test. It was proved by the data which showed that the mean of the students in the post test (80) is higher than the formative test (48.96) and it is also higher than the pre-test (67.12).

The qualitative data which are taken from the observation sheet also showed that students are interested in learning vocabulary through word walls strategy because this strategy can be a solution for them in facing difficulties in learning English vocabulary. The students enjoyed the class and applied the strategy well. The strategy is very useful to help the students to improve their vocabulary mastery which was lack of English vocabulary.

The diary notes indicated that the situation of teaching and learning processes was better from the first to the last meetings. The students were interested, antusiastic, and active during the teaching and learning processes. They paid attention and did the tasks seriously.

Then, from the observation sheets, there was significant progress that was shown in every meeting, especially in cycle II. The students were enthusiastic, active and interested in learning the English vocabulary because they begin to understand the importance of learning English. Some of the students who did not like learning English before this word walls strategy was applied became interested in learning English because they felt it was fun. Their attention became better and their mistakes were reduced.

\section{Discussion}

This Classroom Action Research (CAR) consisted of two cycles and each cycle was conducted in three meetings. Before applying word walls strategy, in the first meeting there was pre-test to get the students' score in mastering English vocabulary, the treatment was begun in the second meeting. The study was done in two cycles. Each cycle was carried out in four steps: planning, action, observation, and reflection.

\section{CONCLUSIONS}

After conducting the study of improving students' vocabulary mastery to the eight grade students of SMP Karya Bhakti Medan through word walls strategy, the writer has found some research findings to answer the problems of the study in the introduction. The writer puts forward the following conclusion and suggestion:

a. The students' vocabulary mastery improved. It can be proved by the results of the test, the pre-test mean score is 48.96 , the formative test mean score is 67.12 and it was significantly improved to 80 in the post-test. The students' improvement was very satisfactory.

b. It can be concluded that word walls strategy as one of strategies in teaching vocabulary is appropriate and effective in improving students' vocabulary mastery.

c. The percentage of students who get the point $\geq 70$ in pre-test is $8 \%$ and it is significantly increased to be $92 \%$ in post-test. It means that the implementation of word walls strategy in improving the students' vocabulary mastery makes them active in the teaching and learning processes.

d. The students are interested in learning vocabulary during the teaching and learning process it could be seen from the diary notes and observation sheet. They are more active in learning vocabulary through word walls strategy. 


\section{BIBLIOGRAPHY}

Anggriani, D. (2012). Improving students' vocabulary achievement through word walls strategy. An Unpublished Sarjana's Thesis, Faculty of Languages and Arts: State University of Medan.

Best, J. W. \& Kahn, J.V.(2002). Research in education ( $7^{\text {th }}$ Ed). New Delhi: Prentice Hall of India.

Brown, H.D. (2000). Teaching by principles: An interactive approach to language pedagogy. San Fransisco: Longman.

Burns, A. (2010). Doing action research in English language teaching: A guide for practioners. Sydney: Macquarie University.

Grabe, W. (2009). Reading in a second language: Moving from theory to practice. New York: Cambridge University Press

Huzairin, Hasan \& Istianto. (2015). Improving students' vocabulary mastery through word wall. A Journal. Faculty of Languages and Arts: Lampung University.

Langan, J. (1990). Reading study skills. New York: McGrand-Hill,Inc.

Limbong, T., \& Simarmata, J. (2020). Menentukan Matakuliah yang Efektif Belajar Daring (Belajar dan Ujian) dengan Metode Multi-Attribute Utility Theory (MAUT). Jurnal Resti, 4(2), 370-376.

Mettetal, G. (2001). The what, why and how of classroom action research. Journal of Scholarship of Teaching and Learning. (JoSoTL), 2(1) 6-13.

Rivers, W. (1989). Communicating in a second language. Theory and practice in language teaching. Cambridge: Cambridge University.

Sari, R. A. (2015). The making of word wall to improve elementary school students English vocabulary. Jurnal Ilmiah Mahasiswa, 4(1), 28-35.

Some Appropriate Strategies in Improving Students' Vocabulary. (2015) (http://vprojas@aol.com), accessed on June 15, 2016

Stahl, R. S. (1999). Vocabulary development: The cognitive foundation of learning to read. Chicago: Cambridge Bookline Books

Thompkins, H. (1997). Learning vocabularies. Oxfordshire: Blustone.

Thornbury, S. (2002). How to teach vocabulary. England: Bluestone.

Wallace, M. (1982). Teaching Vocabulary. London: Biddles.

Word Walls. (2012). (http://www.readingrockets.org/strategies/word_walls), accessed on June 15,2016 